\title{
TANTO INDÍGENA COMO TRADICIONAL: AUTENTICIDAD ESCENIFICADA EN EL ÁMBITO TURÍSTICO DE ZiNACANTÁN, Chiapas
}

\author{
INDigenOUS AND TRAditional: STAged AUTHENTICITY IN \\ The Tourism Field of Zinacantán, Chiapas
}

\author{
Baleun Song* \\ doi: https://doi.org/10.31644/ED.V9.N1.2022.A04
}

\begin{abstract}
Resumen: Este artículo analiza el proceso de producción de la autenticidad en la promoción turística de Zinacantán, Chiapas. Como destino del turismo indígena en la zona, Zinacantán es el lugar donde explícitamente se promociona una experiencia auténtica, garantizando a los turistas la presencia de sus pobladores indígenas y una aproximación a su vida cultural a través de una visita a una casa de familias zinacantecas. Durante el recorrido, el guía y la familia zinacanteca intentan mantener impresiones apropiadas a la demanda del turismo indígena, destacando elementos categorizados como "indígenas" y "tradicionales", y, a su vez, invisibilizando otros que corren el riesgo en colapsar los estereotipos de los turistas sobre Zinacantán y sus pobladores. Este trabajo indaga sobre cómo se produce la autenticidad en este ámbito turístico y cómo es presentada la familia zinacanteca ante los turistas. Finalmente, propone comprender los valores creados en la visita turística como resultado de modelos contemporáneos del turismo indígena, aprovechados estratégicamente por los agentes locales para tener ventajas en el mercado global.
\end{abstract}

Palabras clave: turismo indígena, autenticidad, fachada, Zinacantán, performance.

Abstract: This article analyzes the production process of authenticity in tourism promotion of Zinacantán, Chiapas. As a destination for indigenous tourism in the area, Zinacantán is the place where an authentic experience is explicitly promoted, guaranteeing tourists the presence of its indigenous inhabitants and an approach to their cultural life through a visit to a Zinacanteco family home. During the tour, the guide and the Zinacanteco family try to maintain impressions appropriate to the demand of indigenous tourism, highlighting elements categorized as "indigenous" and "traditional", and, at the same time, making invisible others that run the risk

* Mtra. en Antropología Social, investigadora independiente. Correo-e: brightsong@hotmail.co.kr.

Fecha de recepción: 24/03/2021. Fecha de aceptación: 19/11/2021. Fecha de publicación: 31/01/2022.

(cc) BY-NC-ND

EntreDiversidades. Revista de Ciencias Sociales y Humanidades, Vol. 9, Núm. 1 (18), enero-junio 2022. Páginas: 95-117 ISSN-e: 2007-7610. https://doi.org/10.31644/ED.V9.N1.2022.A04 
of collapsing the tourists' stereotypes about Zinacantán and its people. This paper investigates how authenticity is produced in this tourist environment and how the Zinacanteco family is presented to tourists. Finally, it proposes to understand the values created in the tourist visit as a result of contemporary models of indigenous tourism, strategically exploited by local agents to have advantages in the global market.

Keywords: indigenous tourism, authenticity, front, Zinacantán, performance.

\section{Introducción}

Zinacantán es un municipio de la región de Los Altos de Chiapas, ubicado a 10 kilómetros hacia el oeste de San Cristóbal de Las Casas. Su población es de 41,112 habitantes (INEGI, 2015), de los cuales el 99\% habla lengua tzotzil y el 62\% además habla español (INEGI, 2015). El 64\% de la población se dedica a la actividad agropecuaria, aunque también, en las últimas décadas, la producción artesanal se ha convertido en una de las principales actividades económicas, ${ }^{1}$ en la que participan mayoritariamente mujeres tejedoras que combinan sus tareas en la artesanía con la producción de floricultura, actividad realizada principalmente por los hombres zinacantecos (Bayona, 2013).

Actualmente la cabecera de Zinacantán cuenta con una caseta de turismo en la que cobran 15 pesos mexicanos por la entrada al pueblo; ${ }^{2}$ hay restaurantes, pequeńos comedores y una variedad de tiendas de artesanías ubicados alrededor de la plaza de San Lorenzo; puestos temporales de textiles que se ponen durante la temporada vacacional al lado de la misma plaza y casas que ofrecen la visita turística con o sin agencia de viajes. Es importante aclarar que el último tipo de negocio turístico, ya sea mediante el tour o no, es la actividad turística más representativa de Zinacantán. Es el único tipo de la actividad que se promociona en las agencias de viajes y es el que implica el mayor número de ingreso de turistas al municipio, por lo cual, muchas mujeres zinacantecas coinciden en decir "es lo que hacen en Zinacantán", y es justamente en lo que se enfoca el presente trabajo. ${ }^{3}$

Para realizar esta visita turística, los turistas tienen dos opciones: una es contratar un tour llamado "Pueblos Indígenas", que parte desde San Cristóbal de Las Casas; otra es llegar por su cuenta a Zinacantán y encontrarse con un miembro de la familia involucrada con la industria turística, el cual les invita a hacer un recorrido por su casa. En este caso, las familias trabajan independientemente de las agencias y manejan sus propias visitas turísticas en sus casas. Sin

\footnotetext{
${ }^{1}$ Según Rus (1995), desde 1982 las comunidades indígenas de Los Altos de Chiapas empezaron a producir artesanías para el mercado turístico y la actividad artesanal se fue convirtiendo en una de las actividades alternativas, después de haber un gran desempleo de los migrantes indígenas de la región que trabajaban en las fincas cafetaleras de tierra caliente y en la industria de construcción en Chiapas y Tabasco. Por otro lado, Bayona (2013) menciona que desde la década de 1980 aumentó la demanda de las artesanías indígenas junto con el crecimiento del mercado turístico en San Cristóbal de Las Casas.

${ }^{2}$ Consultado en 2018.

${ }^{3}$ Este artículo es parte de mi tesis de Maestría, Escenificar la cultura: mercantilización, turismo y estrategias de familias de Zinacantán, Chiapas (Song, 2018).
}

EntreDiversidades. Revista de Ciencias Sociales y Humanidades, Vol. 9, Núm. 1 (18), enero-junio 2022. Páginas: 95-117 ISSN-e: 2007-7610. https://doi.org/10.31644/ED.V9.N1.2022.A04 
embargo, su dinámica tampoco se diferencia de la de la visita de las agencias de viaje, ya que sigue prácticamente el mismo esquema del tour. La mayor diferencia es que en el caso de las familias que trabajan sin agencias de viaje las mujeres son las que hacen el papel de guía, encargándose de las explicaciones durante la visita.

El tour "Pueblos Indígenas" o "Chamula y Zinacantán" es uno de los paquetes turísticos más promocionados por las agencias de viajes en San Cristóbal de Las Casas. Precisamente visita dos pueblos cercanos de la ciudad, San Juan Chamula y Zinacantán, ambos destacados por ser reconocidos como "pueblos indígenas", lo que se percibe fácilmente en el mismo nombre de la promoción. Este recorrido sale diariamente, con un horario aproximado entre las 09:30h y las 14:30h. En él, se visita las cabeceras de los dos pueblos. El precio oscila alrededor de 200 y 250 pesos mexicanos, ${ }^{4}$ incluyendo la entrada a la iglesia de San Juan Chamula, un pago a la caseta turística de Zinacantán, el transporte de ida y vuelta y el servicio del guía en espańol o en inglés.

Mientras la visita de San Juan Chamula se centra en su iglesia, caracterizada por su "catolicismo tradicionalista", 5 en Zinacantán se accede a una casa de familia en la que se observan y se experimentan las "costumbres tradicionales", como la elaboración de los textiles en el telar de cintura o la degustación de posh, la bebida alcohólica tradicional de la región. ${ }^{6}$ Aunque esta dinámica depende del guía que acompańe el tour, es lo que generalmente pasa todos los días en ambos pueblos.

En estas visitas turísticas, el término indígena aparece como si fuera un concepto sólido, que no requiere de discusión. En particular, durante el recorrido por Zinacantán, las familias se presentan primeramente como indígenas tzotziles y son descritas como alejadas de la "modernidad occidental". Los turistas experimentan las actividades etiquetadas como elementos de la cultura de Zinacantán, categorizadas dentro de las tradiciones y costumbres ancestrales e indígenas. Además, Zinacantán es donde los turistas visitan "una casa privada” y tienen permitido conversar e interactuar con la familia local. ${ }^{7}$

Según Pereiro (2015), el turismo indígena es un subtipo del turismo étnico y a su vez del turismo cultural, que implica explícitamente la presencia de las comunidades indígenas y los indígenas. Es decir, el sujeto de producción y el objeto de consumo serían necesariamente los indígenas. De acuerdo con el investigador, desde la década de 1990 la demanda del turismo

\footnotetext{
${ }^{4}$ Consultado en 2018.

${ }^{5}$ Es una especie de catolicismo propio del lugar, mezclado con rituales y otros aspectos catalogados como "mayas".

${ }^{6}$ Según Bayona (2015), en estas dos visitas se muestran diferentes aspectos de la cultura "tradicional indígena": "en Zinacantán el escenario turístico se construye mediante la exhibición de la producción y venta de textiles, promocionadas por los guías como 'auténticas artesanías mayas', mientras en San Juan Chamula se oferta un recorrido por algunos espacios sagrados e incluye la observación de 'auténticos rituales indígenas'” (Bayona, 2015: 33).

${ }^{7}$ De hecho, Zinacantán es el único lugar en el que se promociona explícitamente el contacto directo con los habitantes locales en Los Altos de Chiapas. En el caso de Chamula, a pesar de que uno siempre se encuentra con la población chamula, el recorrido se realiza independientemente de ellos. Es más, se ofrece "observar" a los chamulas, pero no necesariamente "interactuar" con ellos. Además, la dinámica en Chamula se centra en pasear por los espacios públicos, tanto en la iglesia como en el panteón del pueblo. Por otro lado, el negocio turístico de San Andrés Larráinzar y Tenejapa se limita a la venta de artesanías en otras localidades como en las tiendas de artesanías en San Cristóbal y en los mercados de artesanías en destinos puntos turísticos. No manejan ofertas turísticas en las propias comunidades y carecen de infraestructura turística dentro de los pueblos.
}

EntreDiversidades. Revista de Ciencias Sociales y Humanidades, Vol. 9, Núm. 1 (18), enero-junio 2022. Páginas: 95-117 ISSN-e: 2007-7610. https://doi.org/10.31644/ED.V9.N1.2022.A04 
indígena ha aumentado con las nuevas tendencias turísticas internacionales, más preocupadas por la naturaleza y la diversidad cultural, "con la creencia occidental de que los pueblos indígenas son los preservadores de los valores humanos más 'auténticos”" (Pereiro, 2015: 23). Esta es justamente la razón por la cual propongo entender el ámbito turístico de Zinacantán bajo esta definición, ya que permite analizar la gran demanda actual — que no necesariamente se comparte con otros destinos turísticos que pueden ofrecer el turismo étnico-, es decir, aquella que desea experimentar un mundo "indígena auténtico" que preserva "sus propios valores no occidentales".

Por otro lado, MacCannell (1973) ha argumentado que la peregrinación religiosa, como origen de los tours, comparte con ellos no solo similitudes organizacionales, sino también un motivo: ambos son búsquedas de experiencias auténticas. Mientras los peregrinos buscan y visitan el lugar de procedencia de un evento religioso, los turistas se trasladan a los lugares buscando conocer la importancia social, histórica y cultural de los mismos (MacCanell, 1973). De este modo, tal como apuntan López y Marín (2010), MacCannell ha propuesto concebir al turista como una especie de "peregrino moderno" que viaja para escapar de la alienación de su cotidianidad en el mundo moderno y con el fin de vivir experiencias "auténticas".

Siguiendo a estos dos autores, la autenticidad que buscan los turistas en Zinacantán se relaciona directamente con la presencia de los zinacantecos y una experiencia, lejana de la vida cotidiana, que garantiza valores devastados en el "Occidente". Precisamente, esto es lo que se promociona en el ámbito turístico de Zinacantán. Este destino turístico produce y exhibe su autenticidad a través de un conjunto de actividades categorizadas como tradicionales, sobre todo, mediante el contacto directo con las familias categorizadas como indígenas, para vender una experiencia auténticamente "tradicional" e "indígena" a los turistas.

Los enfoques que proponen Pereiro y MacCannell han permitido pensar en lo "indígena" y lo "tradicional" como categorías cargadas de valores en sí mismas. Esto me ha posibilitado cuestionar la identificación de las personas como seres indígenas, la cual implica tener en cuenta muchas impresiones e imágenes preconstruidas, típicas y estereotipadas respecto de los habitantes de pueblos como el de Zinacantán. Este trabajo partió desde ahí.

Para aproximarnos a este proceso de la producción de la autenticidad, revisaremos cuatro aspectos. En el primer lugar, analizo la oferta del recorrido turístico por Zinacantán. "Visitar la casa de una familia local" parece ofrecer una experiencia auténtica permitiendo un acceso al espacio íntimo o privado de los locales; sin embargo, lo que se experimenta es otro tipo de escena, armada para la actuación, o, como diría MacCannell (1973), una región posterior escenificada.

En segundo lugar, trato de indagar la fachada (Goffman, 1981) que se muestra en la escena turística de la "Familia de Zinacantán". Durante el recorrido, los actuantes intentan crear y agregar valores de "lo indígena" y "lo tradicional" a la Familia de Zinacantán para presentarla como la "auténtica”. Aquí, escribo la "Familia de Zinacantán” con mayúscula, porque propongo entenderla como un papel de la actuación, creado pensando en la demanda del turismo indígena, y como una máscara de la autenticidad que se pone la familia zinacanteca durante la visita turística. No me refiero a que es una máscara falsa de las familias zinacantecas y que existen las familias

EntreDiversidades. Revista de Ciencias Sociales y Humanidades, Vol. 9, Núm. 1 (18), enero-junio 2022. Páginas: 95-117 ISSN-e: 2007-7610. https://doi.org/10.31644/ED.V9.N1.2022.A04 
"verdaderas", sino que busco enfatizar que durante el tour existe y se observa una producción de autenticidad de las familias zinacantecas; por ello, decidí analizarla con la idea de fachada y otros términos teatrales empleados por Goffman.

En tercer lugar, intento mostrar otros elementos que aparecen idealizados en el recorrido. Además de la fachada presentada durante el tour, los actuantes idealizan a la familia frente a los turistas y esconden/destacan intencionalmente algunos elementos compartibles/incompartibles con la expectativa de los turistas.

Por último, hablaré de los momentos en los que los turistas se sienten engañados, decepcionados o confundidos en la visita turística, cuando al encontrar algo distinto a lo que esperaban, sus nociones preconcebidas acerca de la experiencia turística colapsan (Little, 2004).

Los datos presentados se basan en entrevistas informales y semiestructuradas y en la observación participante que realicé durante cuatro meses de trabajo de campo en 2017 para una tesis de maestría. Conviví con tres familias zinacantecas — una que trabaja con las agencias de viaje, una que trabaja independientemente y otra que no se dedica al turismo- , durante un mes con cada una, hospedándome en sus casas. Durante la convivencia me encontré con varios grupos de turistas, con o sin guías, de varias nacionalidades, en su mayoría mexicanos y europeos. Por otro lado, visité doce agencias de viajes ubicadas en el centro de San Cristóbal de Las Casas. Me presenté como una turista surcoreana que quería consultar los tours alrededor de la ciudad y realicé unas entrevistas informales con los empleados. He de decir que ser originaria de Corea del Sur me facilitó convertirme en turista, ya que también existen imágenes preconcebidas y estereotipadas acerca de los turistas. Así, hice dos veces el tour "Pueblos Indígenas" a través de las agencias de viajes y visité cuatro veces las casas zinacantecas que trabajan de manera independiente. Como turista, saqué fotos e hice entrevistas informales con los demás turistas, los guías y las familias durante las visitas. En el caso de los datos relacionados con los turistas, además de las entrevistas informales, estos se basan principalmente en los conseguidos por vía Internet, a través de la página web TripAdvisor, en la que los viajeros escriben sus experiencias.

Según Goffman (1981), todos actuamos frente a los demás. La actuación (performance) siempre tiene el objetivo de influir de alguna manera en los otros, y en ella tendemos a generar y mantener impresiones apropiadas con nuestra posición social. En Zinacantán, la familia zinacanteca y el guía, actuantes del performance turístico, tratan de crear impresiones atractivas que coincidan con las demandas de los turistas. Además, preparan el escenario adecuado y actúan apropiadamente durante la visita turística, compartiendo así un cierto objetivo en la actuación, generar una ganancia económica. ${ }^{8}$

\footnotetext{
${ }^{8}$ Generar ingresos económicos ha sido el principal motivo y objetivo de participar en el negocio turístico para los zinacantecos involucrados en el turismo - como lo es para los guías y las agencias-. El turismo es una actividad que eligen las familias para involucrarse en el mercado global, ya que les garantiza ciertos ingresos económicos. Este es el enfoque central de este trabajo, orientado hacia la relación entre el turismo y las familias zinacantecas. En este contexto, coincido con Bruner (2005) sobre las percepciones distintas de los turistas y los locales en cuanto a la zona fronteriza (borderzone) turística: para los turistas es una zona de ocio y exotización y para los locales es un sitio de trabajo e ingresos en efectivo.
}

EntreDiversidades. Revista de Ciencias Sociales y Humanidades, Vol. 9, Núm. 1 (18), enero-junio 2022. Páginas: 95-117 ISSN-e: 2007-7610. https://doi.org/10.31644/ED.V9.N1.2022.A04 


\section{"Visitar la casa de una familia zinacanteca"}

Realizar una visita a la casa de la familia zinacanteca significa acceder al hogar donde viven y en el que las mujeres elaboran diariamente las artesanías. Si un turista decide contratar este tour, llega al interior de la casa y observa los trabajos artesanales de las mujeres de la familia. Mientras tanto, puede regatear el precio de los recuerdos directamente a las mujeres, charlar con ellas y preguntar cosas y tomarse fotos con ellas. Es decir, además de conocer los espacios de la casa y los trabajos de la familia, los turistas tienen permitido tener un "contacto" con las mujeres zinacantecas. También, la visita ofrece experimentar algunas costumbres de Zinacantán, tanto degustar el posh, como probarse la vestimenta zinacanteca.

\section{Fotografía 1. Folleto informativo del tour "Pueblos Indígenas" de agencias de viaje}

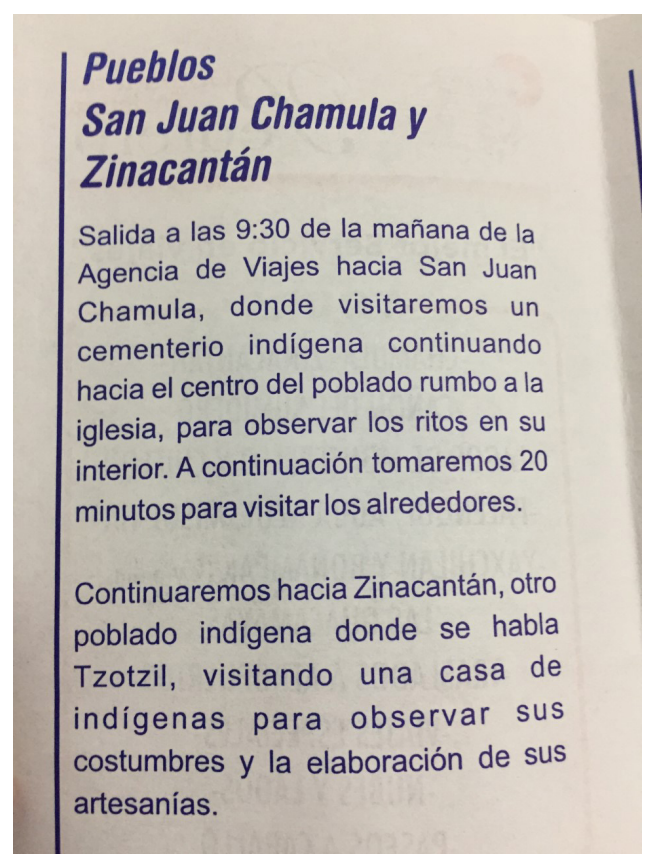

Fuente: Baleun Song, 2017, San Cristóbal de Las Casas, Chiapas, México.

Esta promoción ofrece una experiencia que al parecer garantiza una aproximación a las costumbres de la familia, la presencia de los zinacantecos y el acceso a un espacio privado de Zinacantán. Es una experiencia distinta a la de llegar a los museos, donde no están presentes los zinacantecos; como lo es a presenciar algún baile tradicional en un restaurante céntrico de la ciudad de San Cristóbal. En esta visita a la casa de una familia zinacanteca subyace la promesa de la posibilidad de experimentar las regiones posteriores (Goffman, 1981) ${ }^{9}$ de Zinacantán, donde aparentemente se muestra algo que está más allá de las cosas fosilizadas que existen en otros escenarios: la parte "auténtica" de los zinacantecos.

\footnotetext{
${ }^{9}$ Goffman (1981) identificó dos regiones diferentes desde el punto de vista de una actuación particular: región anterior (front region) y región posterior (back region). La primera se refiere a donde tiene lugar la actuación; la segunda es el espacio donde se prepara la actuación y donde los actores descansan de los papeles de la actuación.
}

EntreDiversidades. Revista de Ciencias Sociales y Humanidades, Vol. 9, Núm. 1 (18), enero-junio 2022. Páginas: 95-117 ISSN-e: 2007-7610. https://doi.org/10.31644/ED.V9.N1.2022.A04 
Sin embargo, para la familia es un espacio de actuación, en la que los actuantes se mueven bajo un guion armado. Además, los espacios de la casa que están abiertos a los turistas siempre se arreglan pensando en la visita foránea, preparándose intencionalmente con los detalles que muestra el guía durante el tour. Por ejemplo, una de las familias de esta investigación tiene dos cocinas en la misma casa, una es familiar y otra es exclusivamente para los turistas. En la primera cocina tienen utensilios "prohibidos" en la escena, como estufa del gas y licuadora, cosas que pueden romper con las imágenes "auténticas" que los turistas esperan encontrar. La segunda cocina está llena de objetos "tradicionales" que representan lo indígena, como el metate, los maíces de cuatro colores de Chiapas, un comal de leña, etc., que son siempre destacados por el guía durante el recorrido. En este caso, los turistas nunca llegan a conocer la cocina familiar, a pesar de que ambas comparten el mismo patio. Es decir, la "casa" ofrecida a los visitantes es un escenario estratégicamente escenificado y construido para atraer a los turistas, igual que los otros escenarios turísticos, como los museos o los espectáculos de baile tradicional. Según MacCannell (1973), este espacio es la región posterior escenificada (staged back region) y es un tipo de museo vivo (living museum). Esta región es construida solo para los turistas y se abre únicamente para los visitantes externos en determinados momentos. Por lo tanto, se diferencia de la región posterior institucional de Goffman y es un tipo de región anterior (MacCannell, 1973).

Sung (2005) argumenta que el acceso a esta parece ofrecer una entrada al espacio íntimo y privado de los locales. Conocer la costumbre y la tradición de un destino turístico estando en la región posterior escenificada suele hacer sentir a los turistas la continuidad de la cultura de la localidad, por lo cual les invita a pensar que la escena turística muestra "lo vivo" del lugar y no "lo disecado” como en los museos (Sung, 2005). El acceso a la región posterior escenificada entonces funciona como garantía de autenticidad en la dinámica de la puesta en escena.

Sin embargo, como bien lo menciona MacCannell (1973), no toda autenticidad o todo en la vida real de los locales agrada a los turistas. Algunos detalles que pasan en la vida cotidiana pueden ser molestos y los turistas pueden sentirse incómodos con ellos. Por tanto, la autenticidad que pretenden mostrar los actuantes en el tour es estratégicamente seleccionada y escenificada. Los detalles mostrados como representativos de la autenticidad forman parte de la "autenticidad agradable", es decir, se trata de aquellos que de alguna manera satisfacen la demanda de los turistas o que al menos no los decepciona; un buen ejemplo se produce en el tour cuando se explican los símbolos mayas con una blusa de San Andrés Larráinzar —otro pueblo cercano- en el cuarto de artesanías, pero no se dice su verdadera procedencia:

El guía explicaba acerca de los textiles mostrando las cosas específicas. Agarró una blusa que tenía el bordado de unas figuras y explicó: "También es importante en la cultura maya, algunos símbolos que ellos manejan [indicando unas figuritas], es la ranita en la cultura maya y representa la lluvia. Las ranas únicamente cuando se acerca la lluvia empiezan a despertar y cantar. Por eso, cuando canta la ranita viene la lluvia. [...] representan mariposas, cocodrilos. También los rombos. Los rombos son los que representan el centro del universo, como el altar que vimos" (Diario de campo, septiembre de 2016).

EntreDiversidades. Revista de Ciencias Sociales y Humanidades, Vol. 9, Núm. 1 (18), enero-junio 2022. Páginas: 95-117 ISSN-e: 2007-7610. https://doi.org/10.31644/ED.V9.N1.2022.A04 
Las tejedoras zinacantecas no elaboran estos símbolos destacados por el guía, sino que compran este tipo de artesanías a los vendedores que llegan de San Andrés. Aunque el guía sabe que estos símbolos no se comparten en Zinacantán y que son comprados de otro municipio, no lo menciona, y aprovecha para brindar sus explicaciones de la cultura maya, ya que los zinacantecos son también categorizados como "mayas".

Además, los guías tratan de controlar la dinámica de la visita para que no aparezcan elementos desagradables. Por ejemplo, durante el tour "Pueblos Indígenas" es fácil encontrar a los turistas batallando con los niños vendedores de pulseras, muñequitos y otro tipo de artesanías. Muchas veces, los turistas rechazan la venta y simplemente ignoran a los niños que insisten en que compren algo. Para evitar esta escena incómoda, algunos guías avisan a los turistas de que no les hagan caso a los vendedores:

Desde la plaza principal pasamos unas tres cuadras y nos paramos enfrente de una casa y el guía nos dijo, "Llegamos", así que ya preparaba mi mochila para bajarme del transporte. [...] Ya nos bajamos de la camioneta y entramos directamente a la casa. Había algunos vendedores de accesorios de ámbar pero nadie les hizo caso porque al bajarnos el guía nos dijo, "Van a ofrecer el ámbar y les van a quitar un poquito de tiempo. Entonces, vamos a pasar directamente" (Diario de campo, septiembre de 2016).

Esta dinámica del tour, que sucede en lo que yo propongo entender como la región posterior escenificada, tiene un cierto efecto, que es generar la impresión del acceso al espacio privado e íntimo de la familia zinacanteca. Sin embargo, esto no significa el acceso a la región posterior de la familia. Las casas siempre están preparadas para ofrecer una experiencia auténtica agradable y los actuantes controlan otros elementos desagradables para no incomodar a los turistas. Para algunos, esta experiencia puede ser entendida como auténtica, aunque para otros será artificial o demasiado montada. Lo seguro es que esta promoción de vivir una experiencia que es algo más que visitar museos y mirar un espectáculo, sin duda es una de las razones por las que los turistas eligen realizar el tour "Pueblos Indígenas" y es el atractivo específico del recorrido de Zinacantán.

\section{La Familia de Zinacantán: “indígena” y "tradicional”}

La fachada (front), entendida por Goffman (1981), es "la dotación expresiva de tipo corriente empleada intencional o inconscientemente por el individuo durante su actuación” (1981:34). Aquí la fachada suele trasmitir el carácter abstracto y general que esperan o requieren los observadores de la actuación respecto a nuestra posición social.

Para presentar a una familia zinacanteca ante los turistas, en el ámbito turístico de Zinacantán se produce un modelo ideal que tiene estrecha relación con el carácter abstracto y general que esperan los turistas del turismo indígena: "los pueblos indígenas son los preservadores de los valores humanos más 'auténticos' y están más próximos a la naturaleza y a un medio ambiente

EntreDiversidades. Revista de Ciencias Sociales y Humanidades, Vol. 9, Núm. 1 (18), enero-junio 2022. Páginas: 95-117 ISSN-e: 2007-7610. https://doi.org/10.31644/ED.V9.N1.2022.A04 
considerado muy devastado en Occidente" (Pereiro, 2015: 23). Es la fachada de la Familia de Zinacantán, a la que recurren los guías y zinacantecos, relacionada con la autenticidad constituida en virtud de su carácter "indígena” y "tradicional".

Por ejemplo, en el tour, al dar las explicaciones del telar de cintura y de la elaboración de los textiles, el guía destaca que el telar de cintura es la máquina prehispánica cuya técnica se hereda de mujer a mujer, y que con ella se diseñan representaciones mayas. Así, durante todo el recorrido el guía enfatiza los términos "tradicional" e "indígena”, ya que presentar una imagen típica y exótica muchas veces funciona como evidencia de que la familia es "auténtica”. Es decir, la fachada de la familia que es mostrada en la puesta en escena representa que la misma es "tan indígena" y "tan tradicional", que es "la auténtica".

Goffman (1981) argumenta que la fachada social se puede dividir en tres partes, el medio, la apariencia y los modales, ${ }^{10}$ y que con frecuencia esperamos que las tres tengan una coherencia entre ellas. Los actuantes de la escena turística de Zinacantán lo intentan también.

Los espacios de la casa a los que tienen acceso los turistas deben mantener lo más posible la forma tanto "indígena" como "tradicional". El mejor ejemplo del medio sería la cocina. Lo siguiente es un extracto de mi diario del campo, cuando pasé a la cocina de una familia zinacanteca en el tour que tomé por primera vez como turista surcoreana:

La cocina estaba aún más oscura que los otros espacios. Tenía no más que una ventana chiquita y una puerta por la que se podía salir a un pequeño terreno de la familia. La cocina era de adobe y la pared parecía totalmente quemada. Había dos mujeres preparando tortillas, sentadas en el suelo, cerca de la estufa de leńa que tenía un comal puesto. Una era joven, de 15 o 18 años y otra mujer era grande, de 50 o 60 años. Las dos llevaban un mandil bordado de flores y estaban hincadas de rodillas haciendo tortillas. Cada una hacía bolitas de masa, las aplastaba en una maquinita de tortillas de madera y las ponía en el comal. [...] Era impresionante, sobre todo el ambiente que tenía la cocina. La pared quemada aumentaba el ambiente de extrañeza junto con la luz oscura y el humo que salía de las leńas prendidas. Todo participaba de la creación de ese ambiente, el olor del humo, el movimiento de las mujeres, el sonido que hacen la leña quemándose... también las mujeres hablando entre ellas en tzotzil. Todas las cosas que se daban ahí, alrededor de las mujeres, según mi mirada no tan amplia, generaban un ambiente totalmente lejano, misterioso y exótico. Es así que me dije, “¿Qué loco estar en este lugar!” (Diario de campo, septiembre de 2016).

En esa cocina no hay licuadora, refrigerador, ni mesa de comedor, o muchas veces estos elementos están invisibilizados en el recorrido. ${ }^{11}$ Así, las mujeres aparecen en la escena manteniendo la

\footnotetext{
${ }^{10} \mathrm{El}$ medio (setting) se refiere a los elementos escénicos que permanecen fijos en el escenario, la apariencia (appearance) sería los estímulos que funcionan al informar el estatus social del actuante, y los modales (manners) son los estímulos que funcionan al informar el rol de la interacción (Goffman, 1981).

${ }^{11}$ Por ejemplo, yo misma, unas semanas después del tour, revisé unas fotos que había sacado durante el recorrido y ahí me di cuenta de que en el salón de la casa de familia zinacanteca había una televisión sobre un armario de madera. No me acordaba de esa escena en mis propias memorias del lugar, y su presencia en la foto entonces armaba una escena totalmente nueva. En mi etnografía tampoco tenía nada escrito sobre la televisión. En cambio, en mi memoria tenía imágenes muy claras del altar de la familia, las fotos de la familia en las que sus miembros
}

EntreDiversidades. Revista de Ciencias Sociales y Humanidades, Vol. 9, Núm. 1 (18), enero-junio 2022. Páginas: 95-117 ISSN-e: 2007-7610. https://doi.org/10.31644/ED.V9.N1.2022.A04 
"autenticidad" de ser "indígenas tradicionales": están vestidas con el traje "tradicional” y entre ellas hablan su idioma "indígena”. Luego, siendo anfitrionas de la casa, reciben a los turistas con una sonrisa generosa y con una actitud abierta y no arrogante. La mayor parte de su participación se limita a mostrar su tradición "auténtica", la que practican en su vida cotidiana. Hacen tortillas a mano y tejen en el telar de cintura; sus modales (manners) no pasan más allá de la "familia zinacanteca" que se alegra de presentar "lo suyo" ante los foráneos.

El guía toma un papel distinto, que es el de estimular la fachada de la Familia de Zinacantán, y así enfatiza sus tres partes — el medio, la apariencia y los modales_- destacando lo indígena y lo tradicional a través de sus explicaciones. Por ejemplo, remarca que la manera de hacer tortillas es original, que la familia se viste de manera tradicional hasta la fecha y que las mujeres de la casa están a gusto con que los turistas conozcan sus trabajos, entre otros aspectos más.

Para producir la fachada, hay veces que los guías exageran las explicaciones o "inventan" algunos asuntos. En algunas ocasiones durante el trabajo de campo escuché a las mujeres zinacantecas diciendo: "Los guías inventan cosas". En una ocasión, apenas terminada una entrevista con una mujer cuya familia trabaja con los guías, ella me mostró unos cojines que tenían unos brocados de tres triángulos montados y le pregunté si tenían algún significado. Entonces, ella me dijo: "No. Nomás lo ponemos así. Pero los guías inventan cosas, cualquier cosa. Cuando estoy haciendo tortillas [en la visita turística], a veces escucho lo que dice el guía. Dicen que los triángulos que tenemos en algunos textiles, los ponemos porque hay cerros aquí [en Zinacantán]. Dicen que los triángulos son cerros. Además, les pusieron el nombre, 'rombo', pero no lo es" (Conversación personal, Zinacantán, 6 de octubre de 2018).

En otra ocasión, estaba realizando una entrevista con una mujer cuya familia recibe a los turistas independientemente de las agencias. Esta vez le hice la misma pregunta, pero indicando otro brocado de un cojín que tenía forma de rectángulo. En un contexto muy similar al anterior, ella me respondió: "No. Así son, pues. No significan nada. Es que ya los [significados] ponen después. Muchos dicen que los triángulos que ponemos, es porque hay tres cerros sagrados. ${ }^{12}$ Por eso dicen que son tres puntas de triángulos. Pues hay cerros, pero no sé si así significan para ellos" (Entrevista, Zinacantán, 18 de diciembre de 2018). Asimismo, varios miembros de las familias involucradas en el turismo compartían una imagen de los guías como "mentirosos" y como "los que inventan cosas".

estaban vestidos de trajes típicos y la mesa con las botellas de posh, entre otras cosas de las que el guía había dado explicaciones. Es decir, en el tour en el que el guía enfatiza unos elementos específicos, otros elementos no destacados simplemente habían sido invisibilizados.

${ }^{12}$ Vale mencionar que Greenfield (2004) destaca un patrón de "montaña” brocado del que posiblemente devienen las explicaciones de "cerros sagrados" de los guías. Según ella, era un diseño nuevo que crearon las mujeres de Navenchauc en los años 90. El brocado tiene forma de zigzags triangulares de variedad de colores y las mujeres lo nombraban como "montañas", relacionándolo con una gran montaña triangular del valle de Navenchauc, considerada como montańa sagrada. Así es como ella presenta ese brocado, diciendo, "[el brocado] tiene su fuente en las antiguas creencias mayas" (Greenfield, 2004: 113). Puede que el patrón de los tres triángulos que tejen actualmente las mujeres zinacantecas devenga de ese mismo patrón de "montaña", aunque los dos patrones no parecen tener un diseño común más allá de las formas triangulares. Sin embargo, actualmente las mujeres tejedoras no comparten este significado y para ellas el significado "tres cerros" es una invención de los guías.

EntreDiversidades. Revista de Ciencias Sociales y Humanidades, Vol. 9, Núm. 1 (18), enero-junio 2022. Páginas: 95-117 ISSN-e: 2007-7610. https://doi.org/10.31644/ED.V9.N1.2022.A04 
"Lo indígena” y "lo tradicional” no son categorías independientes, sino que están entrelazadas y muchas veces son mencionadas por el guía en contextos similares. En algunas ocasiones el guía utiliza ambos términos incluyendo otro, “original”, como si tuvieran el mismo significado. Por ejemplo, con respecto al "traje indígena", el guía podía sustituir dicho concepto inmediatamente por "traje tradicional" o "traje original", y aun así no cambiaba mucho el contexto en el que estaba dando la explicación. De hecho, la autenticidad de la familia en la que el guía hace énfasis se basa en que la familia siga manteniendo o no haya perdido "su tradición", la cual mostrada en la puesta en escena muchas veces consistía en hablar el idioma, vestirse de traje, practicar los rituales y las costumbres, entre otras cosas, que han definido a la familia como "indígena”.

En cambio, si una familia o un/a zinacanteco/a ya no se viste con el traje, habla más el español que el tzotzil y no participa en los rituales, su autenticidad podría ser cuestionada. Lo siguiente es una parte del discurso del guía en el que describe el modernismo como la maldad que hace perder a los zinacantecos su tradición ancestral y auténtica:

El guía empezó a presentar a la familia: "Bienvenidos a esta familia que se le denomina Don Lorenzo" ${ }^{13}$. Justo en este momento pasaba un señor de la tercera edad que llevaba el traje zinacanteco bien bordado de flores y resultó que era Don Lorenzo. [...] "Como vimos al señor, ya no vemos a nadie en el centro [de la cabecera de Zinacantán]. Todos ya tienen ropa normal. Practican el modernismo. El modernismo ha venido a cambiarles también muchas costumbres de ellos. Han venido dejando lo tradicional, y ya han adoptado lo moderno" (Diario de campo, septiembre de 2016).

Después, el guía indicó una foto antigua en la que salía Don Lorenzo vestido del traje y mencionó:

"Así ha sido el vestido de Don Lorenzo, de muy niño hasta la fecha, 80 años, original. Así deberían ser todos los hombres de Zinacantán. Nada más que el modernismo llegó, ahora usan botas, chamaras de piel, pantalón vaquero, sombrero, pues, ya olvidaron lo que es original. Don Lorenzo siempre ha sido así. Toda la ropa que trae, está hecha en el telar de cintura" (Diario de campo, septiembre de 2016).

Así, cuando el guía recurre al discurso del modernismo, la fachada se enfatiza aún más. Además de diferenciar a la familia del tour de las otras familias "no auténticas" o "menos auténticas", también marca la diferencia de la "modernidad". Si rastreamos estos discursos del guía, no es difícil encontrar a qué se refiere, aunque sea en un contexto muy abstracto. El modernismo significa ya no vestir el traje zinacanteco, ya no hablar el idioma y ya no hacer tortillas a mano, entre otras cosas. No se refiere solo a practicar la "modernidad": hablar en español, utilizar microondas y ponerse los jeans, etc. Más bien se trata de perder la autenticidad de ser indígena y ser tradicional, así como de ser zinacanteco. ${ }^{14}$

\footnotetext{
${ }^{13}$ El nombre Don Lorenzo es ficticio.

${ }^{14}$ En estos discursos subyace una visión simplista sobre la tradición y la modernidad indígena que argumenta Neila (2014): aquella que describe a los individuos como en permanente resistencia contra los campos sociales, políticos y
}

EntreDiversidades. Revista de Ciencias Sociales y Humanidades, Vol. 9, Núm. 1 (18), enero-junio 2022. Páginas: 95-117 ISSN-e: 2007-7610. https://doi.org/10.31644/ED.V9.N1.2022.A04 
Una cosa que muestra bien la fachada de la Familia de Zinacantán es la foto más representativa de la visita: una mujer zinacanteca vestida del traje tejiendo en el telar de cintura. Esta foto es la que generalmente utilizan las agencias de viajes en las oficinas y en sus páginas de Internet para promocionar el tour 'Pueblos Indígenas'. De hecho, en los tours, la parte más fotografiada por los turistas es cuando la mujer muestra cómo elaborar los textiles en el telar de cintura, junto con la mujer haciendo tortillas a mano. Es así que en las páginas de viajeros aparecen muchas fotos de mujeres tejiendo, y si buscamos "turismo de Zinacantán" en el buscador Google, también encontramos numerosos retratos similares, entre otros propios del municipio, como los de la fiesta. Es decir, que para muchos turistas esta imagen es la primera que conocen de Zinacantán antes de trasladarse, es lo típico que uno capta con su cámara después del tour.

Fotografía 2. Mujer zinacanteca tejiendo en el telar de cintura

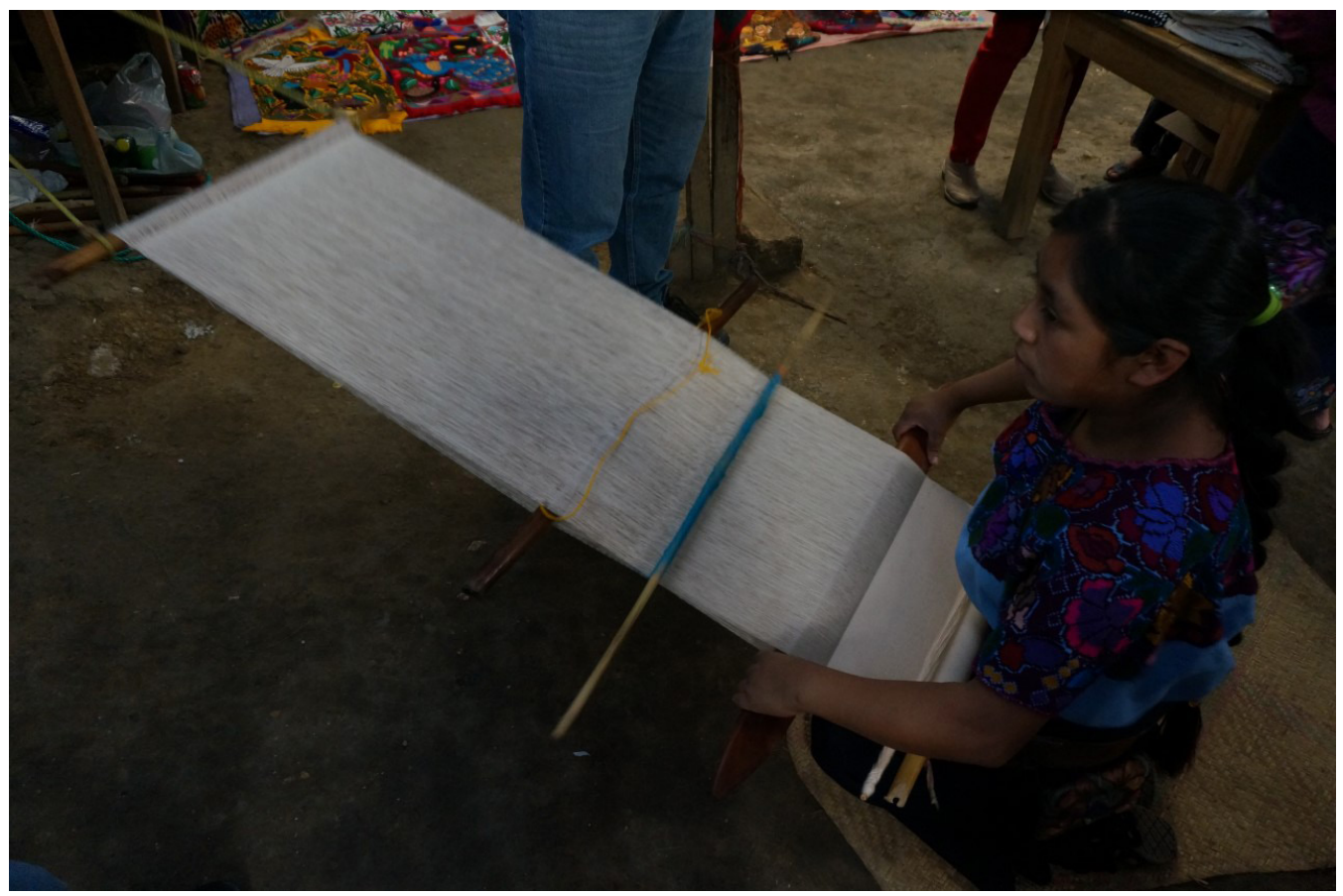

Fuente: Baleun Song, 2016, Zinacantán, Chiapas, México.

económicos más que en interacción con las transformaciones contemporáneas. Además, esta visión del guía coincide suficientemente con la creencia occidental que se relaciona con la demanda del turismo indígena que argumenta Pereiro (2015).

EntreDiversidades. Revista de Ciencias Sociales y Humanidades, Vol. 9, Núm. 1 (18), enero-junio 2022. Páginas: 95-117 ISSN-e: 2007-7610. https://doi.org/10.31644/ED.V9.N1.2022.A04 
Fotografía 3. Dos mujeres zinacantecas torteando en la cocina

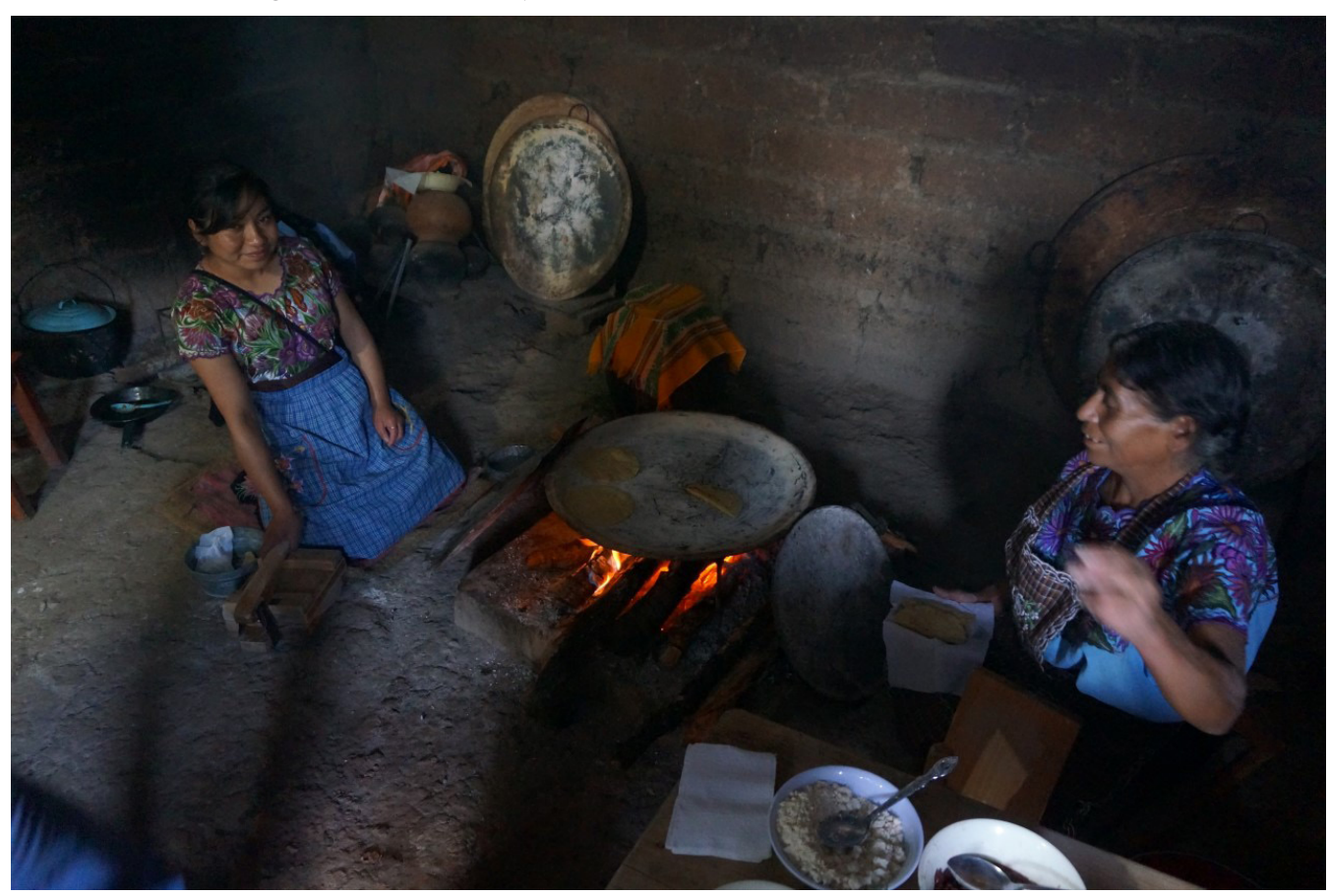

Fuente: Baleun Song, 2016, Zinacantán, Chiapas, México.

\section{La idealización}

Los actuantes tienden a ofrecer de diversas maneras una impresión idealizada ante los observadores; para lograrla, algunos elementos del performance pueden ser enfatizados o pueden estar encubiertos (Goffman, 1981). En el ámbito turístico de Zinacantán también se observan ciertas circunstancias estratégicamente destacadas por los actuantes, que son idealizadas o por lo menos sospechosas. Una de las cosas en las que se pone énfasis en el tour es que la familia que recibe a los turistas "no es como las demás”. Aunque esos “demás” no están específicamente mencionados, lo que es muy evidente es que hay una distinción de la familia entre los demás "otros".

Los elementos principalmente diferenciadores son que la familia del tour es más "generosa” y más "abierta" que "las demás". ${ }^{15}$ Lo es, según el guía, porque permite entrar a su casa a los turistas; ofrece las tortillas y el posh entre otras cosas, además, los ofrece gratis y deja sacarles fotos. ${ }^{16} \mathrm{O}$ sea, que la familia es tan generosa que "les comparte a los turistas lo que es para la familia" y al mismo

\footnotetext{
${ }^{15}$ Como he mencionado en el apartado anterior, estos caracteres también constituyen una parte de los modales de la fachada.

${ }^{16}$ En los recorridos por Zinacantán siempre se advierte que tomar fotos de la familia está totalmente permitido. Así como en el caso de las familias que no trabajan con las agencias de viajes, cuando reciben a los turistas en sus propias casas, siempre los invitan a sacar fotos libremente en la casa. Es una gran diferencia en comparación con lo que pasa en la visita de San Juan Chamula, ya que en la iglesia de Chamula, que es el lugar central del recorrido, está totalmente prohibido tomar fotos.
}

EntreDiversidades. Revista de Ciencias Sociales y Humanidades, Vol. 9, Núm. 1 (18), enero-junio 2022. Páginas: 95-117 ISSN-e: 2007-7610. https://doi.org/10.31644/ED.V9.N1.2022.A04 
tiempo es tan abierta que "les deja pasar a su espacio privado y personal". Además, el guía impone la idea de que ofrecer toda esa generosidad no es algo que todo el mundo hace. Durante el trabajo de campo tuve varias oportunidades de observar las visitas guiadas en la casa. En una de ellas, al dar explicaciones en la cocina, el guía enfatizaba la generosidad de la familia y dijo: "Aquí todavía se recibe a las visitas con café y con la comida, lo que ya hace tiempo que no hacemos". Luego las mujeres aparecen en la escena turística como actrices, reciben a los turistas con una sonrisa "generosa" y muestran toda la actividad sin exceder la exigencia de las compras y las propinas. Así, tanto el guía como la actuación de las mujeres de la familia colaboran en la idealización de la familia como "generosa" y "abierta". Un buen ejemplo de ello es el siguiente comentario de una turista mexicana que visitó una casa de las familias que trabajan sin guías:

Claro que vale la pena: es triste leer los malos comentarios sobre este pueblo. Chiapas es un estado sumamente pobre y si cobran $\$ 15$ pesos ${ }^{17}$ o no, hay que pagarlos con gusto (a nosotros no nos cobraron). La gente es muy amable, literal te abren las puertas de su casa y te invitan de lo poco que tienen. [...] Hay una cooperativa de mujeres, estando en el parque nos invitaron a ir $^{18} y$ aunque no está a dos cuadras como te dicen, vale mucho la pena, encontramos cosas muy padres. De verdad la ropa y los bordados son un regalo. Nos trataron súper bien, nos dieron a probar pox [posh] de nance, nos hicieron tortillas a mano. Es importante conocer el trabajo de las mujeres, es importante ver cómo viven para valorar lo que tenemos. Ir a Chiapas es enriquecerse, es un viaje que cambia la perspectiva de vida. Vayan, conozcan, visiten, compren, y por favor NO regateen con los artesanos, demos valor a su trabajo. KOLABAL ${ }^{19}$ Chiapas (SibaritaWannabe, Ciudad de México, México, 1 de abril de 2018) (TripAdvisor, 2018).

En la puesta en escena, los turistas no alcanzan a observar a las mujeres contando las propinas o con caras preocupadas por si nadie se anima a comprar, ni tampoco al guía pidiendo a la familia las comisiones por haber llevado a los turistas a su casa. Hacer la cuenta, mostrar preocupaciones y negociar con el guía suelen ser aspectos propios de la región posterior, cuando ya no están los turistas en casa.

La segunda parte destacable de la idealización se relaciona con la manera en que vive la familia. El guía enfatiza que vivir "tradicional" de alguna manera es "mejor" que vivir como "nosotros". En este caso, la distinción que hace el guía ya no diferencia una familia idealizada como generosa de otras familias zinacantecas, sino que los "otros" ahora son los foráneos de la visita, o los que no viven de la misma manera que la familia. Estos "otros", muchas veces se refieren a un "nosotros", los que escuchan al guía, es decir, los turistas, e incluso, el guía mismo. Lo siguiente son las explicaciones del guía sobre la cocina y la gastronomía de la familia zinacanteca durante el tour:

\footnotetext{
${ }^{17}$ Se refiere al pago de entrada que se cobra en la caseta del turismo de Zinacantán. Los turistas tienen que pagar la entrada en la caseta, excepto los que utilizan transportes públicos.

${ }^{18}$ Las familias que manejan visitas turísticas sin agencias de viajes, las promocionan propiamente en el centro de la cabecera de Zinacantán. Las mujeres salen cada día a ofrecer una visita a su casa entre los turistas que llegan al pueblo en transportes públicos.

${ }^{19}$ Gracias, en tzotzil.
}

EntreDiversidades. Revista de Ciencias Sociales y Humanidades, Vol. 9, Núm. 1 (18), enero-junio 2022. Páginas: 95-117 ISSN-e: 2007-7610. https://doi.org/10.31644/ED.V9.N1.2022.A04 
"Esta cocina es de puro adobe. Esto no lo movió ni siquiera el temblor. Es la mejor. Aunque muchos indígenas ya han cambiado a la cocina moderna, aquí esta familia mantiene la tradicional. Otras casas tienen su microondas, su horno, su cocina integral, y ya no se ve nada original. Pero esta familia sí. Ahí pueden ver cómo se hace tortillas. La forma de hacer tortillas es original. Estas tortillas no van a ver en ningún lado de San Cristóbal. [...] Ellos son también vegetarianos, porque no comen carne por lo regular. Comen verduras, maíz, generalmente. Los frijoles nunca les van a faltar, los aguacates, los tomates y las tortillas son las cuatro cosas que comen a diario. La edad de vida de ellos es entre 80 y 100 ańos, aunque no todo el mundo llega" (Diario de campo, septiembre de 2016).

El guía mencionó que la cocina ni se había movido por el temblor debido a que "esta cocina es de puro adobe”. La cocina fue lo único que destacó el guía en la construcción de la casa, ya que el resto de la casa era de blocks. Luego explica que los zinacantecos tienen una expectativa de vida más larga porque "son vegetarianos" y "no comen carne por lo regular" ${ }^{20}$. Además, destaca la sanidad de la comida, agregando que los frijoles son de la propia cosecha de la familia. Aquí, el menú "bien sencillo" que ofrece la familia se convierte en el menú "sano" que "consume diario la familia".

La última impresión idealizada en la puesta en escena es aquella producida diferenciando a Zinacantán de Chamula. Las características de Chamula más destacadas por el guía son que los locales son "cerrados", "machistas" y "radicales", que son adjetivos que no se encuentran en la explicación sobre la gente de Zinacantán. Por ejemplo, cuando el guía explica la actividad económica de Chamula, menciona: "Pero ojo, trabajan únicamente las mujeres. El dinero se le entrega al hombre porque el hombre es el que administra. Así se rige en Chamula" (Diario de campo, septiembre de 2016). Esto los distingue de los hombres zinacantecos cuando el guía dice: "los caballeros [zinacantecos] llegan a los invernaderos. No es como Chamula. Aquí los hombres trabajan también y las damas trabajan de las artesanías" (Diario de campo, septiembre de 2016).

En comparación con Chamula, la impresión de Zinacantán es totalmente contraria. Esta imagen de que "no son tan cerrados", "ni machistas", no solo se afirma cuando el guía hace una comparación directa entre ambos pueblos, sino también se admite cuando impone la impresión "generosa" de la familia o enfatiza que las mujeres zinacantecas son autónomas porque manejan el negocio turístico y son "las que mandan” en casa. A los turistas se les hará aún más razonable toda esta comparación al visitar Chamula, donde no se les permite tomar fotos y donde el guía cuenta más anécdotas de los chamulas, describiéndolos como el pueblo indígena másconservador. ${ }^{21}$

\footnotetext{
${ }^{20}$ Zinacantán tiene varios platos típicos de carne. Hacen caldos de pollo, de res y de cerdo; también se suele comer asados en el comal y ahumados con leña. Dependiendo del nivel económico de la familia, el consumo de carne varía, y es cierto que algunos platos de carne siguen siendo platos especiales para las fiestas. Sin embargo, la explicación del guía es muy exagerada.

${ }^{21}$ Algunas de las anécdotas más presentes en los escenarios turísticos de Chamula son: a) Chamula es el único pueblo autónomo en Chiapas que resistió la conquista espańola y al que no pueden entrar ni el gobierno estatal ni la policía; b) los chamulas son católicos tradicionales que no han permitido a los conversos evangélicos y que los han expulsado del pueblo, de manera sumamente violenta; c) en 2016 los chamulas mataron al presidente municipal que era del Partido Verde por no haber cumplido sus promesas políticas.
}

EntreDiversidades. Revista de Ciencias Sociales y Humanidades, Vol. 9, Núm. 1 (18), enero-junio 2022. Páginas: 95-117 ISSN-e: 2007-7610. https://doi.org/10.31644/ED.V9.N1.2022.A04 
La idealización de los actuantes es realizada durante todo el proceso de actuación. Al destacar unos elementos y a su vez invisibilizar otros, la idealización funciona para desarrollar la "autenticidad agradable" durante el recorrido. Si la actuación termina exitosamente, bajo el guion armado por los actuantes, los turistas regresarán con esas imágenes idealizadas de la familia "auténtica”, tan "generosa” y "abierta" que "vive lo bueno".

\section{El colapso de los turistas}

No obstante, no todas las actuaciones llegan a tener éxito. La impresión construida puede ser destrozada en cualquier momento de la actuación. Si bien la coherencia expresiva es requerida durante toda la puesta en escena, "la impresión de realidad fomentada por una actuación es algo delicado, frágil, que puede ser destruido por accidentes muy pequeños” (Goffman, 1981: 67). Sucede lo mismo en los escenarios turísticos. Cuando los turistas encuentran algún detalle discrepante a la impresión general del performance, se sienten confundidos, decepcionados y hasta engañados. Por un detalle muy pequeño, la impresión que se va acumulando durante el tour se puede derrumbar.

Según Little (2004) los turistas llegan al destino turístico con su imagen preconcebida sobre los locales. En su ejemplo, los turistas tendían a llegar al mercado de artesanías en Antigua, Guatemala, a buscar a los indígenas "auténticos", que para ellos muchas veces eran las mujeres que llevaban el traje típico y que hablaban en un idioma (Little, 2004). ${ }^{22}$ En el caso de Zinacantán, también algunos turistas tienen cierta imagen de los zinacantecos en cuanto a su vestimenta. Si uno lleva el traje típico de Zinacantán para ellos muchas veces significa que es zinacanteco. Un ejemplo que puede servir como aproximación, es que durante el trabajo de campo las familias que participaron en esta investigación me ponían a veces el traje completo. Cuando yo estaba vestida de traje, sentada entre las familias, muchos turistas no me reconocían como extranjera ni foránea. Algunos me preguntaban el precio de las artesanías pensando que era una mujer de la casa. ${ }^{23}$ En cambio, cuando no me ponía el traje, los turistas fácilmente me clasificaban como extranjera y asiática, aunque estuviera tejiendo en el telar de cintura o bordando unas flores, y me preguntaban cosas como, de dónde venía, qué estaba haciendo en Zinacantán, cuánto tiempo llevaba en México, etc.

Las nociones preconcebidas pueden ser trastornadas cuando los turistas encuentran lo contrario, aquello que no cabe en los estereotipos, o cuando los turistas y los locales actúan fuera del papel prescrito (Little, 2004). Así, cuando los turistas observan lo que no han pensado que harían los locales, su noción preconcebida colapsa.

\footnotetext{
${ }^{22}$ Además de esa imagen preconcebida en cuanto a los indígenas "auténticos", Little (2004) agrega que los turistas tienen nociones preconcebidas sobre la profesión, los papeles de género y étnicos, de los mayas y no mayas locales, y también de los demás turistas. La literatura describe a los mayas como especialistas de rituales, agricultores, tejedores y vendedores, pero no como profesores de la universidad, médicos, cajeros del banco, abogados, etc. Estos mayas de ocupación generalmente eliminada en la literatura suelen pasar inadvertidos por los turistas (2004).

${ }^{23}$ Sin embargo, para los zinacantecos, me veía siempre foránea.
}

EntreDiversidades. Revista de Ciencias Sociales y Humanidades, Vol. 9, Núm. 1 (18), enero-junio 2022. Páginas: 95-117 ISSN-e: 2007-7610. https://doi.org/10.31644/ED.V9.N1.2022.A04 
Como los caracteres destacados de la Familia de Zinacantán en la puesta en escena están seleccionados pensando en las demandas de los turistas, las nociones preconcebidas de los turistas hacia Zinacantán muchas veces coinciden con las impresiones del escenario turístico creadas por los actuantes. Estas se relacionan con los caracteres de lo indígena y lo tradicional del municipio, que generalmente son los términos utilizados como oposición a "lo moderno", y que terminan dando evidencias de "lo auténtico".

A continuación muestro un ejemplo de otro tour, cuando fui con una amiga coreana que me visitaba con un plan de viaje. En este caso, mi amiga tenía una cierta noción preconcebida sobre "lo indígena" como persona de bajo nivel económico y lejano de la modernidad: ${ }^{24}$

Estábamos pasando por la carretera para los pueblos [Chamula y Zinacantán]. En medio del camino el guía mencionó una casa gigante que aún estaba en obra, indicándola: "Miren, va a ser una casa muy bonita. Estos indígenas ${ }^{25}$ son bastante indiscretos de la economía. Así vamos a encontrar los carros de BMW, puros de ellos". ${ }^{26}$ La casa era de dos pisos, era de blocks, y todavía estaba totalmente despintada. Tenía decoraciones de unas flores y venados en su fachada. Algunos turistas sorprendidos comentaron que la casa parecía como un castillo. Mi amiga también pareció bastante sorprendida. Ahí, me preguntó: "Oye, pero, ¿no es amenazante para los demás indígenas? No deberían ostentar tanto sus riquezas, ¿no?” (Diario de campo, 30 de octubre de 2016).

Primero a ella le sorprendió la casa "moderna” de los indígenas. Luego, el comentario de mi amiga aludió a que esa casa gigante que mostraba un alto nivel de riqueza no era algo que ella pensaba mirar en los pueblos indígenas. En su noción preconcebida no existían los indígenas ricos o modernos, ni chamulas ni zinacantecos. Al mirar esa casa colapsó su estereotipo acerca del indígena y también la dicotomía moderno/tradicional y rico/pobre.

Sin embargo, en Zinacantán, el performance turístico que se realiza en el tour de agencias de viaje corre relativamente menos riesgo de generar el colapso, debido a que la dinámica del mismo es medio cerrada y bien armada. Como el recorrido está centrado en la visita a una familia que ya está esperando a los turistas, la dinámica no llega generalmente hasta fuera de la casa de la familia.

En el caso de Zinacantán, el colapso que suele ocurrir se relaciona con el motivo por el que los turistas realizan los recorridos: la búsqueda de la autenticidad. Aquí, la definición de la autenticidad varía en cada turista y para algunos la experiencia auténtica puede ser experimentar aspectos culturales y tradicionales. En una ocasión, visité Zinacantán con un amigo argentino que también andaba de viaje. Esa vez fuimos sin contratar un tour. Llegamos a la plaza principal

\footnotetext{
${ }^{24}$ Little (2004), parafraseando a MacCannell, mencionó que estas nociones preconcebidas de los turistas constituyen una serie de dicotomías de turistas/locales como modernos/primitivos, civilizados/incivilizados, y urbanos/rurales (Little, 2004: 42). En el caso de mi amiga la dicotomía sería rico/pobre y moderno/tradicional.

${ }^{25}$ El guía no indicó que eran chamulas o zinacantecos, así que los turistas entendieron solo que eran indígenas.

${ }^{26}$ En este caso, los guías lo mencionan para generar en los turistas el colapso con cierta intención, porque este colapso surgido de la idea de "indígenas ricos", de alguna manera funciona para que la familia zinacanteca a la que visitan sea aún más "tradicional" y "auténtica". Además, vale aclarar que no es que el colapso resulte siempre en desencanto. Para algunos turistas puede ser un motivo por tener mayor interés por conocer los lugares turísticos.
}

EntreDiversidades. Revista de Ciencias Sociales y Humanidades, Vol. 9, Núm. 1 (18), enero-junio 2022. Páginas: 95-117 ISSN-e: 2007-7610. https://doi.org/10.31644/ED.V9.N1.2022.A04 
de Zinacantán y una chica vestida de zinacanteca se acercó a nosotros diciendo: “¿Quieren ver artesanías? Los invito a mi casa y les muestro cómo hacer el telar y les invito las tortillas y el posh también”. Ella nos llevó a su casa y así visitamos a una familia que no trabajaba con las agencias de viaje:

En el salón había una señora de 40-50 años. Al vernos, nos preguntó: “¿Quieren ver el telar de cintura?" y se sentó en el telar. La chica que nos trajo a la casa ya había salido de la casa [o sea, nos entregó a la señora y se fue]. La señora ya sentada en el telar empezó a mostrarnos cómo elaborar el textil, pero en cinco minutos se levantó del telar diciendo: "Ya, ¿no?”. [...] como había muchísimas artesanías exhibidas en el cuarto, empezamos a mirarlas. La señora nos acompañaba y nos mostraba más productos. Decía el precio de los textiles y otros detalles. Mi amigo se animó a comprar un corazoncito [una decoración que se puede colgar en las paredes] de 50 pesos. Así, pasamos como 10 minutos mirando las artesanías. La señora nos acompañaba solamente. Mi amigo me dijo que ya saliéramos de la casa. [...] O sea, la señora no se animó a mostrar más actividades. No nos invitó a entrar a la cocina, ni a probar el posh, nada. Caminamos hacia la plaza, y mi amigo me dijo: "Así, no es lo que quiero ver yo. Yo cuando vengo a los pueblos, quiero ver algo de aquí. Eso no es visitar una casa. Ese lugar fue una tienda, no más" (Diario de campo, mayo de 2017).

Antes de visitar Zinacantán mi amigo mencionó que había decidido visitar San Cristóbal de Las Casas por varias razones: para conocer los factores culturales y tradicionales de la región; porque había escuchado que San Cristóbal tenía un clima agradable para viajar; también porque era una ciudad de paso entre Cancún y Ciudad de México, los cuales eran sus destinos principales de viaje. Después de la visita mi amigo se quedó muy decepcionado. Resultó que él había comprado el corazoncito porque le daba pena solamente estar mirando las cosas y lo compró para ya salir de la casa. Luego profundizó en las razones por las que se había decepcionado:

"Tenía más expectativas, pero fue un poco simple... No pienso que me aportaron nada cultural. Me imaginaba que era un poco más participativo. Es decir, con un poco más de explicación, algo que no se dio. Estaba mostrando el telar, pero [de parte de la señora] no hubo mucho interés en mostrar algo... como la forma, la tradición y la historia, no. [...] Pasa que la experiencia [la visita a la casa] que he vivido no me parece tan auténtica. Por lo menos, no ha sido enriquecedor. No considero que hoy fue sumamente enriquecedor culturalmente" (Diario de campo, mayo de 2017).

La visita no le convenció porque no se dio ninguna aportación cultural para él. La chica nos invitó a "su casa" diciendo que nos ofrecería probar el posh y las tortillas hechas a mano, pero el espacio al que llegamos, para él, fue más bien "una tienda” de artesanías. Además, la señora nos mostró el telar de cintura solamente para cumplir lo que nos había prometido mostrar. Mi amigo se sentía engañado y la autenticidad de la visita fue cuestionada por él.

EntreDiversidades. Revista de Ciencias Sociales y Humanidades, Vol. 9, Núm. 1 (18), enero-junio 2022. Páginas: 95-117 ISSN-e: 2007-7610. https://doi.org/10.31644/ED.V9.N1.2022.A04 
Además, este deseo de experimentar lo auténtico de Zinacantán que muchos turistas llevan después de escuchar la oferta de la "visita a la casa", puede colapsar cuando uno siente que el recorrido es demasiado artificial o comercial. En la página web del TripAdvisor, por ejemplo, varios comentarios de los turistas expresaban su decepción o molestia por la artificialidad y la comercialidad que habían sentido en los escenarios turísticos de Zinacantán. A continuación, presento uno de ellos:

Sin encanto: definitivamente un lugar que sus costumbres ancestrales han hecho un negocio muy rentable. No estoy en contra de que vivan del turismo, pero a diferencia de San Juan Chamula aquí es un abuso. No puedes tomar fotografías de ningún lado y uno puede pensar que es por respeto a las tradiciones pero no es así. No te lo permiten porque es el negocio, si quiere fotos debes de pagar. ${ }^{27} \mathrm{Me}$ enoja que vistan a los nińos con trajes típicos y los manden a corretear turistas para ganarse unos pesos a cambio de una foto. Todos los tours y taxistas te llevan a la misma casa a que conozcas el telar de cintura, lo cual también es un fiasco ya que cuando llegas sale corriendo una señora y se pone a tejer para que le tomes fotos, terminada la sesión de fotos se levanta, jajaja. Pero bueno a pesar de la actuación es una belleza todos los tejidos muy muy coloridos y eso es lo que hace que valga la pena la visita. Estas prendas son caras pero si analizas el trabajo que implica realizar una sola te darás cuenta que bien vale pagar el costo (Serene RVV, Ciudad de México, México, 30 de marzo de 2017). ${ }^{28}$

En este caso, la intención de crear la autenticidad a través de "la visita a la casa de una familia zinacanteca" fracasó y resulta que el deseo de la experiencia auténtica de los turistas colapsó.

Así, los turistas se decepcionan y se sienten confundidos cuando encuentran algo que no han esperado en los destinos turísticos. Esto no es agradable no solo para los turistas, sino también para los locales. Según Little (2004), el colapso de la noción preconcebida de los turistas puede llegar a dificultar el consumo, debido a que el destino turístico no lograría ser reconstruido de una manera positiva por ellos. Además, el colapso hace dudar de la autenticidad de la experiencia turística. Por lo tanto, muchas veces a los actuantes les conviene mostrar los estereotipos de los turistas en contextos coherentes y mantenerlos durante la actuación. Sin embargo, aun así, el colapso puede ocurrir en cualquier momento, no solo porque el escenario está menos preparado, sino también por la noción preconcebida o los estereotipos sobre los zinacantecos que traen los turistas.

\footnotetext{
${ }^{27}$ En el centro de la cabecera de Zinacantán hay algunos niños y mujeres que cobran por ser fotografiados. Muy probablemente se refiere a ellos, ya que en las casas que reciben a los turistas permiten sacar fotos sin problema.

28 Disponible en: https://www.tripadvisor.com.mx/ShowUserReviews-g1026028-d7210959-r471438371Zinacantan-Zinacantan Southern Mexico.html (Consultado el 1 de octubre de 2021).
}

EntreDiversidades. Revista de Ciencias Sociales y Humanidades, Vol. 9, Núm. 1 (18), enero-junio 2022. Páginas: 95-117 ISSN-e: 2007-7610. https://doi.org/10.31644/ED.V9.N1.2022.A04 


\section{Reflexiones}

La dinámica que se ha revisado anteriormente es lo que generalmente se comparte en el ámbito turístico de Zinacantán. El tour "Pueblos Indígenas" es el único recorrido de las agencias que transportan a los turistas a Zinacantán y todas las agencias ofertan la misma dinámica del recorrido por el municipio. Además, los turistas que llegan al pueblo por su propia cuenta terminan muchas veces con la misma dinámica del tour, pero en las casas de familias que no trabajan con las agencias.

Es decir, la mayoría de los involucrados en el turismo de Zinacantán muestra la misma actuación a los turistas y ofrece explicaciones semejantes sobre los mismos elementos; aunque las explicaciones varían, muchas veces se centran en los mismos aspectos: lo indígena y lo tradicional de la familia.

Así es como en el ámbito turístico la mayoría de las familias zinacantecas se convierte en la Familia de Zinacantán. Quizás los turistas de diversas nacionalidades visiten las casas de distintas familias, sin embargo, terminan conociendo a la misma Familia de Zinacantán. Aquí, para convertir a las diversas familias en la Familia de Zinacantán, los guías las homogeneizan destacando elementos esencializados y romantizados a través de las explicaciones y sus discursos sobre modernidad/tradición. También, las diversas familias zinacantecas, para convertirse en la Familia de Zinacantán, se homogeneizan a sí mismas preparando y mostrando los elementos esencializados y romantizados a través de su actuación visual.

El turismo ha sido una gran actividad económica para muchas familias de Zinacantán y por ello muchas otras familias intentan involucrarse en esta industria. Las familias ya involucradas, en las escenas actúan el papel de la Familia de Zinacantán, participando en la producción de estos valores sobre lo indígena y lo tradicional, por lo cual ganan sus propios ingresos. Pero fuera de las escenas, viven su vida no necesariamente tan "tradicional” ni "indígena”, sin la máscara de la Familia de Zinacantán. Además, esa distinción de tradición/modernidad, tan claramente marcada en la escena, vista desde el ángulo de las familias zinacantecas de esta investigación, es un invento, más bien una estrategia para generar mejores impresiones ante los turistas consumidores. Las familias a las que este estudio refiere viven en un momento de la contemporaneidad en el que coexisten dos categorías sin una división clara entre ellas. Lo paradójico es que tal y como ha contribuido a marcar la distinción modernidad/tradición, el turismo es también una de las fuentes de cambios.

La autenticidad y los valores indígena y tradicional tampoco son tan ajenos de lo que ocurre en la distinción tradición/modernidad presentada en la escena turística. Son también algo que se inventa y se busca en el ámbito turístico. Pero como he insistido en este artículo, estos imaginarios son los que aprovechan las familias zinacantecas involucradas en el turismo. Las mujeres saben que "los guías inventan cosas", pero, para ellas, es lo que hacen los guías como parte del equipo de la actuación. Tal vez les moleste que exageren cosas que realmente no son así para ellas, pero son conscientes de que el turismo funciona de esa manera, y ellas siguen produciendo los textiles cuyos significados se convierten en los inventos de los guías. Además, lo aceptan porque saben que así los guías les traen más visitantes; trabajar con el guía es también un negocio estratégico de las familias y muchas veces privilegiado para involucrarse en el mercado global. Al cumplir

EntreDiversidades. Revista de Ciencias Sociales y Humanidades, Vol. 9, Núm. 1 (18), enero-junio 2022. Páginas: 95-117 ISSN-e: 2007-7610. https://doi.org/10.31644/ED.V9.N1.2022.A04 
con esas imágenes típicas y permitir el invento de los guías, las familias se presentan en la escena turística de esa forma. Por este motivo este trabajo propone entender esta cuestión como una estrategia de las familias que saben manejar totalmente cómo venderse en el ámbito turístico.

Mi intención a lo largo del artículo no ha sido enfocarme o profundizar en la autenticidad que buscan los turistas, más bien lo que he intentado hacer es analizar la producción de este término abstracto que muchos turistas desean, pero que todo el mundo interpreta a su manera. Tanto en mi papel de investigadora como en el de turista, la autenticidad ha sido una palabra misteriosa, que de repente tiene todo el sentido y de pronto no dice nada. Para algunos turistas Zinacantán se convierte en un pueblo indígena que mantiene su tradición auténtica y para otros termina siendo un destino demasiado turístico que abusa a los turistas. Así como para algunos la autenticidad inesperada en Zinancantán es algo decepcionante que al final no consideran como parte de la misma autenticidad, para otros es algún nuevo descubrimiento en su experiencia verdaderamente auténtica. Por tanto, cada turista en Zinacantán moldeará su propia noción de la autenticidad.

Mi intención al hablar de la autenticidad no ha sido analizar si realmente la visita es auténtica o no, sino entenderla como un valor creado en el escenario turístico. Tampoco se trata de decir que el performance es un show falso y que entonces la vida cotidiana es real. No me interesa si podemos llamar a las tortillas hechas a mano una costumbre auténtica de Zinacantán, sino más bien cómo los actuantes hacen que tortear parezca la auténtica costumbre de Zinacantán. Y sostengo que los que deciden si es falsa o verdadera, si la experiencia es auténtica o no lo es, no son los guías ni son los zinacantecos, ni soy yo: son los turistas que consumen esa experiencia y esa autenticidad escenificada. Cada turista se lleva distintas impresiones en un mismo tour, y eso no solo por la variedad de las autenticidades que van buscando, sino que también se relaciona con miles de actitudes y contextos que tienen ellos, muchas veces desde tiempo antes siquiera de pensar en hacer el viaje. Del mismo modo, como analizó MacCannell (1973) en un contexto similar, no hay salida para los turistas mientras presionen en su búsqueda de autenticidad.

\section{Bibliografía citada}

Bayona Escat, Eugenia (2013). “Textiles para turistas: tejedoras y comerciantes en los Altos de Chiapas”. Pasos. Revista de Turismo y Patrimonio Cultural [en línea], 11 (2), pp. 371-386. doi: https://doi.org/10.25145/j.pasos.2013.11.024 (Consultado el 10 de marzo de 2021).

Bayona Escat, Eugenia (2015). "Rituales indígenas y otras escenificaciones turísticas en los Altos de Chiapas". Nueva Antropología. Revista de Ciencias Sociales [en línea], Núm. 82, pp. 38-78. También disponible en: https://revistas-colaboracion.juridicas.unam.mx/ index.php/nueva-antropologia/article/view/15346/13686 (Consultado el 10 de marzo de 2021).

Bruner, Edward M. (2005). "Introducción: Travel Stories Told and Retold" y "7. The Balinese Borderzone", en Culture on Tour: Ethnographies of Travel. United States of America: The University of Chicago Press, pp. 1-29 y pp. 191-210.

EntreDiversidades. Revista de Ciencias Sociales y Humanidades, Vol. 9, Núm. 1 (18), enero-junio 2022. Páginas: 95-117 ISSN-e: 2007-7610. https://doi.org/10.31644/ED.V9.N1.2022.A04 
Goffman, Erving (1981). La presentación de la persona en la vida cotidiana. Buenos Aires, Argentina: Amorrortu Editores.

Greenfield, Patricia Marks (2004). Tejedoras: Generaciones Reunidas. Evolución de la Creatividad entre los Mayas de Chiapas. México, D. F., México, Sna Jtz'ibajom, A.C., Centro de Investigaciones y Estudios Superiores en Antropología Social, Editorial Fray Bartolomé de Las Casas, A.C., Ediciones Universidad Católica de Chile.

Instituto Nacional deEstadísticay Geografía(INEGI) (2015).Panoramasociodemográfico de Chiapas 2015 [en línea]. Ciudad de México, México: Instituto Nacional de Estadística y Geografía. Disponible en: https://www.inegi.org.mx/contenido/productos/prod serv/contenidos/ espanol/bvinegi/productos/nueva estruc/inter censal/panorama/702825082154.pdf (Consultado el 1 de octubre de 2021).

Little, Walter (2004). Mayas in the marketplace. Tourism, Globalization, and Cultural Identity. United State of America: University of Texas Press.

López Santillán, Ángeles A. y Marín Guardado, Gustavo (2010). “Turismo, capitalismo y producción de lo exótico: una perspectiva crítica para el estudio de la mercantilización del espacio y la cultura”, Relaciones. Estudio de Historia y Sociedad [en línea], 31 (123), pp. 219-258. doi: http://dx.doi.org/10.24901/rehs.v31i123.648 (Consultado el 12 de marzo de 2021).

MacCannell, Dean (1973). "Staged Authenticity: Arrangements of Social Space in Tourist Settings". American Journal of Sociology, 79 (3), pp. 589-603.

Neila Boyer, Isabel (2014). Amor y otras tecnologías. La miscelánea de la 'modernidad' tzotzil en Chiapas. Tesis para obtener el grado de Doctorado en Diversidad, Subjetividad y Socialización, Estudios de Antropología Social y Cultural, Escuela Internacional de Doctorado Universidad Nacional de Educación a Distancia, España. Disponible en: http://e-spacio.uned.es/fez/eserv/tesisuned:Filosofia-Ineyla/NEILA BOYER Isabel Tesis.pdf (Consultado el 12 de marzo de 2021).

Pereiro Pérez, Xerardo (2015). "Reflexión antropológica sobre el turismo indígena”. Desacatos. Revista de Ciencias Sociales [en línea], Núm. 47, pp. 18-35. https://desacatos.ciesas.edu. mx/index.php/Desacatos/article/view/1419 (Consultado el 14 de marzo de 2021).

Rus, Jan (1995). "Local Adaptation to Global Change: The Reordering of Native Society in Highland Chiapas, Mexico, 1974-1994". European Review of Latin American and Caribbean Studies [en línea], Núm. 58, pp. 71-89. http://www.jstor.org/stable/25675662 (Consultado el 25 de julio de 2018).

TripAdvisor (2018). Claro que vale la pena. Opinión sobre Zinacantán [en línea]. TripAdvisor. Disponible en: https://www.tripadvisor.com.mx/ShowUserReviews-g1026028d7210959-r570284852-Zinacantan-Zinacantan Southern Mexico.html (Consultado el 1 de octubre de 2021).

EntreDiversidades. Revista de Ciencias Sociales y Humanidades, Vol. 9, Núm. 1 (18), enero-junio 2022. Páginas: 95-117 ISSN-e: 2007-7610. https://doi.org/10.31644/ED.V9.N1.2022.A04 

escenificada en el ámbito turístico...

Song, Baleun (2018). Escenificar la cultura: mercantilización, turismo y estrategias de familias de Zinacantán, Chiapas. Tesis para obtener el grado de Maestría en Antropología Social, Centro de Investigaciones y Estudios Superiores en Antropología Social (CIESASSURESTE). También disponible en: https://ciesas.repositorioinstitucional.mx/jspui/ handle/1015/1000

Sung, Tae-kyu (2005). "A Case Study and Anthropological Rethinking on Cultural Tourism". Northeast Asia Tourism Research, 1 (1), pp. 15-34 (en coreano). 